\title{
Article \\ Allelopathic Efficiency of Plant Extracts to Control Cyanobacteria in Hydroponic Culture
}

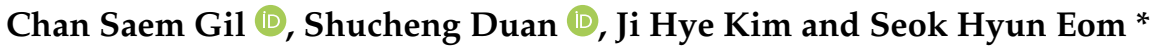 \\ Department of Horticultural Biotechnology, Institute of Life Sciences \& Resources, Kyung Hee University, \\ Yongin 17104, Korea; cskil@khu.ac.kr (C.S.G.); dsc97@khu.ac.kr (S.D.); jhkim96@khu.ac.kr (J.H.K.) \\ * Correspondence: se43@khu.ac.kr
}

\begin{abstract}
Cyanobacteria rapidly form harmful algal blooms (HABs) that cause serious nutritional imbalances in crop production via hydroponics. Allelopathic extracts from plants can be applied as a solution for ecologically sustainable control of algal blooms. In this study, the effects of 11 aqueous extracts of 10 allelopathic plants in controlling Microcystis aeruginosa were evaluated. Among the extracts, walnut husk and rose leaf extracts exhibited high inhibitory levels for efficient control of algae. High inhibitory levels were achieved owing to large amounts of water-soluble tannins, especially tannic acid. The effective extracts were applied to a hydroponic system cultivated on leafy perilla vegetables. Although the severe doses $\left(\mathrm{IC}_{90}\right)$ did not guarantee complete algal control due to partial algal regrowth, walnut husk and rose leaf extracts only exerted strong persistent effects on algae control. Persistent algae inhibition contributed to the increase in perilla growth and leaf quality. Rose leaf was potentially a more useful resource for controlling algae in a hydroponic system because the application of rose leaf extract efficiently controlled the algae and was less toxic to perilla growth. In contrast, the treatment of walnut husk extract also controlled algae but inhibited perilla growth with pale green leaves.
\end{abstract}

J.H.; Eom, S.H. Allelopathic Efficiency

of Plant Extracts to Control

Cyanobacteria in Hydroponic

Culture. Agronomy 2021, 11, 2350.

https://doi.org/10.3390/

agronomy 11112350

Academic Editors: Nikos Tzortzakis,

Daniele Massa and

Bart Vandecasteele

Received: 2 November 2021

Accepted: 19 November 2021

Published: 19 November 2021

Publisher's Note: MDPI stays neutral with regard to jurisdictional claims in published maps and institutional affiliations.

Copyright: (c) 2021 by the authors. Licensee MDPI, Basel, Switzerland. This article is an open access article distributed under the terms and conditions of the Creative Commons Attribution (CC BY) license (https:// creativecommons.org/licenses/by/ $4.0 /)$.

Keywords: allelopathy; aqueous extract; cyanobacteria; eco-friendly algaecides; hydroponics; regrowth; tannic acid

\section{Introduction}

Hydroponics is an efficient culture system for producing crops in facilitated agriculture. It is known that the growth rate of hydroponic crops is up to $50 \%$ faster than that of soil crops [1]. Hydroponics can benefit from the automatic control of irrigation and fertilization, ensuring a clean culture-environment and saving space due to multi-layer vertical production [2]. Despite these advantages, the occurrence of cyanobacteria is a main cause of giving up the hydroponics. Cyanobacteria naturally occur and thrive in hydroponic solutions as well as in eutrophic ponds, lakes, and rivers. They damage the ideal hydroponic solution by forming harmful algal blooms (HABs) quickly [3]. Particularly, with the recent increase of indoor farms, the HABs in hydroponics are regarded as troublesome. It is generally accepted that over-formed HABs will negatively affect the nutritional balance to crop growth by consuming nutrients in the solutions, competition with the crops, and blocking the solution filters [4-6]. Additionally, cyanotoxins, which are generated by secondary metabolic processes in some species of cyanobacteria, are potentially hazardous to human health [7].

Microcystis aeruginosa is a main hazardous cyanobacterial species whose algal blooms are easily found in aquatic environments around the world [8]. There are many methods to control the species, such as salvage, coagulation, and using copper-based algaecides [9]. However, the methods cannot be generally applied in mild-scale hydroponic systems, due to their low efficiency, difficulty in managing resources, and occurrence of secondary pollution $[3,9,10]$. Therefore, a practical and eco-friendly alternative method is required to control cyanobacteria. 
Allelopathy is an inhibitory effect of substances produced in the secondary metabolism of plants and microorganisms that interfere with the normal growth of surrounding organisms [11]. Previous studies have reported various allelopathic plants whose extracts inhibit growth of other organisms [12-16]. The allelopathic plants can produce allelochemicals, which degrade cellular structures and negatively affect physiological responses of other organisms $[17,18]$. There are various allelochemicals, including terpenes, phenolics, aromatics, tannins, alkaloids, and flavonoids [19-23]. Since the allelochemicals are derived from plants, many attempts have been conducted to use the allelochemicals or extracts containing the chemicals as eco-friendly algaecides [3,24,25]. However, these attempts have focused on controlling algae rather than considering their impact on hydroponic crops. This may discourage the use of allelopathy for hydroponic crops. Due to the variety of allelochemicals and their functions, optimal and effective allelochemicals should be selected when they are applied to agriculture. Therefore, this study was conducted to compare the allelopathic effects of 11 aqueous plant extracts on the control of cyanobacteria (M. aeruginosa), to select efficient extracts, and to assess impacts of the extracts in hydroponic culture.

\section{Materials and Methods}

\subsection{Preparation of Aqueous Extracts}

Details regarding the 11 plants used to control cyanobacteria are provided in Table 1. The fresh samples were rinsed with distilled water and freeze-dried (IlShinBioBase Inc., Dongducheon, Korea) for $72 \mathrm{~h}$. The dried tissues were then coarsely ground with a home grinder. The powder (10 g) of each sample was dissolved in $1 \mathrm{~L}$ of $80 \%$ aqueous methanol $(v / v)$, which was agitated using a shaker (Daewonsci Inc., Bucheon, Korea) set to $120 \mathrm{rpm}$ under ambient conditions for 3 days. The extract solution was filtered through filter paper (Whatman No. 3, Maidstone, UK) and the solvent was removed by evaporation using a rotary evaporator (Eyela, Tokyo, Japan). One gram of the evaporated extract was dissolved in $100 \mathrm{~mL}$ of high-performance liquid chromatography (HPLC) grade water (Daejung, Siheung, Korea). The hydrophobics in the extracts were eliminated by fractionation using a fraction funnel with ethyl acetate (Daejung, Siheung, Korea). The fractionated aqueous layer was concentrated using a rotary evaporator. Each aqueous extract was dissolved in an algal culture medium at concentrations ranging from 0.05 to $5 \mathrm{~g} \mathrm{~L}^{-1}$ to determine efficient concentrations to inhibit algal growth by $50 \%\left(\mathrm{IC}_{50}\right)$ and $90 \%\left(\mathrm{IC}_{90}\right)$ of non-treatment.

Table 1. Plant extracts used for screening allelopathic effects on cyanobacteria growth.

\begin{tabular}{ccc}
\hline Species & Common Name & Organ Used \\
\hline Artemisia princeps & Mugwort & Leaf \\
Juglans regia & Walnut & Leaf (L) \\
Juglans regia & Walnut & Leaf \\
Oryza sativa & Rice & Leaf \\
Pinus densiflora & Pine & Leaf \\
Pinus koraiensis & Nut pine & Leaf \\
Pueraria lobate & Kudzu & Leaf \\
Rosa hybrida & Rose & Leaf \\
Sorghum bicolor & Sorghum & Leaf \\
Tagetes erecta & Marigold & Leaf \\
Vitis vinifera & Grape & .
\end{tabular}

\subsection{Algae Culture}

The cyanobacteria $M$. aeruginosa was donated by the Nakdonggang National Institute of Biological Resources (Sangju, Korea) and added into a glass conical flask (2 L) filled with BG11 [26]. The flask was placed in an incubator (Daewonsci Inc., Bucheon, Korea) and cultured under controlled environments. The light level was maintained at $50 \mu \mathrm{mol}$ photons $\mathrm{m}^{-2} \mathrm{~s}^{-1}$ of white fluorescent light for $12 \mathrm{~h}$ per day. The temperature and relative humidity were adjusted to $25 \pm 2{ }^{\circ} \mathrm{C}$ and $85 \pm 1 \%$, respectively. After 7 days, 
a batch of M. aeruginosa was separated from the stock and added into a glass conical flask (500 mL) filled with BG11 containing each allelopathic extract. The number of cells was $102.5 \times 10^{5}$ cells $\mathrm{mL}^{-1}$ in each flask. The algal batches were cultured under the same conditions as the stock culture for 15 days. To confirm mortality, the total medium containing algae, which was treated with $\mathrm{IC}_{90}$ of each extract or non-treatment, were filtered through $0.45 \mu \mathrm{m}$ membrane filter (Advantec Toyo Kaisha Ltd., Tokyo, Japan) to remove the residual extracts. Subsequently, each membrane filter was added into a new flask $(500 \mathrm{~mL})$ filled with extract-free medium and sufficiently stirred at $150 \mathrm{rpm}$ for $12 \mathrm{~h}$. The algae was additionally cultured in an incubator for 7 days.

\subsection{Hydroponic Culture}

The seeds of perilla (Perilla frutescens (L.) Britt.) were sown in plug trays filled with fine perlite (GFC Co., Hongseong, Korea) and cultured under natural sunlight in a greenhouse. After 20 days since germination started, and when there were two pairs of true leaf appearance, seedlings of similar size were selected and transplanted into glass bottles containing $300 \mathrm{~mL}$ of Hoagland solution $[27,28]$. The electric conductivity of the solution was measured to $2.21 \pm 0.1 \mathrm{mS} \mathrm{cm}^{-1}$. The $\mathrm{pH}$ value was ranged from 6.7 to 7.3 . A batch of cyanobacteria was added into the culture bottle. The initial algal concentration was adjusted to $101.6 \times 10^{5}$ cells $\mathrm{mL}^{-1}$. The rose leaf and walnut husk extracts with $\mathrm{IC}_{50}$ and $\mathrm{IC}_{90}$ were added into the culture media. The $\mathrm{EC}$ and $\mathrm{pH}$ after the addition of the algae and extracts were not significantly changed. An air-bubble system was continuously applied over the whole experimental period. The indoor culture room was maintained at $25 \pm 2{ }^{\circ} \mathrm{C}$, $70 \pm 5 \%$ humidity, and $100 \mu \mathrm{mol}$ photons $\mathrm{m}^{-2} \mathrm{~s}^{-1}$ of white fluorescent light for $12 \mathrm{~h}$ per day, respectively.

\subsection{Measurement of Cyanobacteria and Plant Growth Parameters}

As a growth parameter of cyanobacteria, the number of cells was counted every 3 days using a disposable hemocytometer (INCYTO Co., Cheonan, Korea) and an optical microscope (Olympus Inc., Tokyo, Japan) at a magnification of $200 \times$. Algal growth inhibition efficiency (IE) was calculated using cell numbers and the following formula [29]:

$$
\text { IE }(\%)=\left[\left(\mathrm{N}_{\text {Control }}-\mathrm{N}_{\text {Treatment }}\right) / \mathrm{N}_{\text {Control }}\right] \times 100
$$

Three parameters were measured for plant growth, such as fresh weights of perilla plants, leaf dry weight, and chlorophyll content of perilla. The fresh weights were measured every 5 days during the culture period by separating plants from the hydroponic system. The plants after quick measurement of fresh weight were set again in the system. Leaf dry weight and total chlorophyll content were measured using mature leaves which were grown for 15 days in the culture. Total chlorophylls were extracted from dried leaf powder $(1 \mathrm{mg})$ using $80 \%$ acetone $(1 \mathrm{~mL})$ for $24 \mathrm{~h}$. Absorbance of the extract was measured at 645 and $663 \mathrm{~nm}$ using a spectrophotometer (S-4100, Scinco, Seoul, Korea). The total chlorophyll content was calculated by the previously described equation [30].

\subsection{Determination of Tannic Acid Using HPLC}

Ranges of water-soluble tannins in walnut husk, rose leaf, and kudzu leaf extracts were determined using a HPLC (Waters 2695 Alliance HPLC; Waters, Milford, MA, USA). Also, standard tannic acids purchased from Sigma-Aldrich Co. (St Louis, MO, USA) were analyzed with the above extracts in the HPLC. The column was a Kinetex $5 \mu \mathrm{m} \mathrm{C18} 100 \mathrm{~A}(150 \times 4.6 \mathrm{~mm}$; Phenomenex, Torrance, CA, USA). All samples were filtered through a $0.45 \mu \mathrm{m}$ syringe filter before analysis. The mobile phase consisted of water with $0.4 \%$ formic acid (solvent $\mathrm{A}$ ) and acetonitrile (solvent B). The flow rate of the mobile phase was $1.0 \mathrm{~mL} \mathrm{~min}^{-1}$ with $10 \mu \mathrm{L}$ injection of each sample. The gradient program was performed according to previously described methods with modifications [31,32]. The gradient program was as follows: $0-5$ min; $5 \%$ B , 5-10 min; 5-80\% B, 10-15 min; 80-90\% B, 15-17 min; and 90\% B, and then re-equilibrated to the initial gradient. The ranges of tannins were detected at $280 \mathrm{~nm}$. 


\subsection{Statistical Analyses}

All data are shown using mean \pm SE obtained from three experimental replicates $(n=3)$. A one-way ANOVA test was conducted to determine significant differences using SAS software (SAS Institute Inc., Cary, NC, USA). Significant differences were evaluated using Tukey's HSD test at $p<0.05$.

\section{Results and Discussion}

\subsection{Effects of Allelopathic Extracts on Algal Inhibition}

In non-treatment of plant extracts, M. aeruginosa grew rapidly from 3 to 6 days, presenting a logarithmic phase. The cell density reached $750 \times 10^{5}$ cells $\mathrm{mL}^{-1}$ on day 9 (Figure 1). After that, the algal growth did not show significant increase until day 15, exhibiting a stationary phase. The $\mathrm{IC}_{50}$ and $\mathrm{IC}_{90}$ values of each allelopathic extract were determined by using IE values on day 15 .

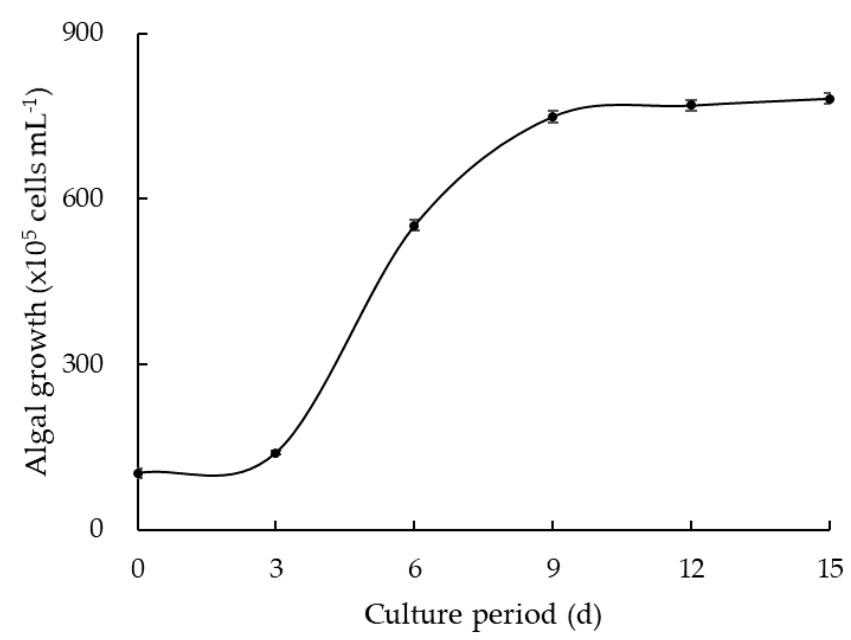

Figure 1. Growth curve of Microcystis aeruginosa in non-treated control group for 15 days of culture.

The $\mathrm{IC}_{50}$ and $\mathrm{IC}_{90}$ values of 11 allelopathic extracts were calculated using exponential decay equations and showed dose-dependent reductions of algal growth with reliable coefficients $\left(r^{2}>0.9\right)$ (Table 2). As described in the study of Shen et al. [33], the exponential decay equation was applied as a rational model to exhibit the allelopathic effect of each extract on the algal growth according to the concentration. Among the extracts, rose leaf extract showed the highest inhibitory effect on algal growth in spite of low-dose treatment.

Table 2. $\mathrm{IC}_{50}$ and $\mathrm{IC}_{90}$ of allelopathic extracts effect on algal growth.

\begin{tabular}{|c|c|c|c|c|}
\hline Species & $\begin{array}{c}\mathrm{IC}_{50} \\
\left(\mathrm{~g} \mathrm{~L}^{-1}\right)\end{array}$ & $\begin{array}{c}\mathrm{IC}_{90} \\
\left(\mathrm{~g} \mathrm{~L}^{-1}\right)\end{array}$ & Equation $^{1}$ & $r^{2}$ \\
\hline R. hybrida & $0.6 \pm 0.04 \mathrm{~d}^{2}$ & $3.5 \pm 0.13 \mathrm{~d}$ & $y=84.66 e-0.61 x$ & 0.977 \\
\hline J. regia $(\mathrm{L})$ & $1.2 \pm 0.03 c$ & $4.1 \pm 0.11 \mathrm{~cd}$ & $y=94.13 e-0.51 x$ & 0.973 \\
\hline P. densiflora & $1.3 \pm 0.06 c$ & $4.3 \pm 0.23 \mathrm{~cd}$ & $y=101.02 e-0.53 x$ & 0.949 \\
\hline J. regia $(\mathrm{H})$ & $1.4 \pm 0.07 c$ & $4.6 \pm 0.22 \mathrm{bcd}$ & $y=106.11 e-0.5 x$ & 0.960 \\
\hline T. erecta & $1.5 \pm 0.10 \mathrm{bc}$ & $5.0 \pm 0.31 \mathrm{bc}$ & $y=101.56 e-0.45 x$ & 0.972 \\
\hline A. princeps & $1.5 \pm 0.01 \mathrm{bc}$ & $5.1 \pm 0.14 b c$ & $y=100.14 e-0.45 x$ & 0.964 \\
\hline$V$. vinifera & $1.4 \pm 0.06 c$ & $5.2 \pm 0.23 \mathrm{bc}$ & $y=101.43 e-0.74 x$ & 0.971 \\
\hline O. sativa & $1.4 \pm 0.07 \mathrm{c}$ & $5.3 \pm 0.26 \mathrm{bc}$ & $y=86.79 e-0.41 x$ & 0.971 \\
\hline S. bicolor & $1.7 \pm 0.05 \mathrm{~b}$ & $5.7 \pm 0.24 b$ & $y=101.38 e-0.40 x$ & 0.986 \\
\hline P. koraiensis & $2.2 \pm 0.07 \mathrm{a}$ & $7.4 \pm 0.34 \mathrm{a}$ & $y=97.84 e-0.31 x$ & 0.971 \\
\hline P. lobata & $2.4 \pm 0.08 \mathrm{a}$ & $7.7 \pm 0.21 \mathrm{a}$ & $y=104.64 e-0.31 x$ & 0.983 \\
\hline
\end{tabular}

${ }^{1} \mathrm{IC}_{50}$ and $\mathrm{IC}_{90}$ were calculated using exponential decay equations. ${ }^{2}$ Different letters within a column indicate significant differences at $p<0.05$ according to Tukey's HSD test. 


\subsection{Algal Regrowth}

In Figure 2, white bars mean IE of $\mathrm{IC}_{90}$ treatment of each allelopathic extract for 15 days. Black bars indicate the changed IE when the algae were transferred to an extract-free medium and cultured for 7 days. Among white bars, there were no statistical differences $(p>0.05)$, which meant that $\mathrm{IC}_{90}$ treatment of each extract favorably exhibited about $90 \%$ of IE. However, the IE values were significantly varied when the algae were transferred to an extract-free medium and cultivated for 7 days $(p<0.001)$. Since transferred to the extract-free medium, the algae treated with most plant extracts had regrown. However, the algae treated with walnut husk and rose leaf extracts hardly regrew, exhibiting high IE values of over 70\% (Figure 2). Canton et al. [34] suggested that the growth inhibition was overcome when favorable environmental conditions for algal growth returned, such as lower concentrations or disappearance of algal inhibitors from the medium. The algal regrowth indicates that allelopathic effect is exhausted, so it is no more crucial in the mortality of algae [17]. The persistent allelopathy may be influenced by the allelopathic extract characteristics. Compared with other extract treatments, the walnut husk and rose leaf extract treatments had persistent allelopathic effects on algal mortality (Figure 2). Several walnut organs contain juglone, a strong allelochemical [35,36]. Juglone is extremely hydrophobic and insoluble in algal medium. Therefore, it is suggested that the inhibitory effect of walnut husk extract may have been induced by hydrophilic allelochemicals. Walnut husk extract contains a high content of phenolic compounds with a large portion of tannic acid [37]. Tannic acid is a water-soluble compound and its allelopathic effects on other microorganisms have been reported [38,39]. Therefore, the analysis of tannic acid in walnut husk, rose, and kudzu leaf extracts was conducted using HPLC.

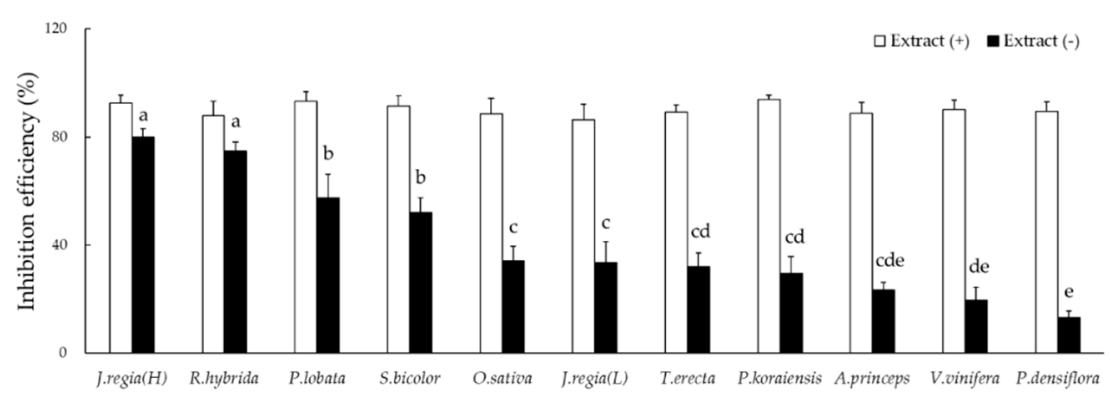

Figure 2. Algal inhibition efficiency rates of 11 allelopathic extracts at $\mathrm{IC}_{90}$ application for 15 days of culture (white bars) and the changed-rates after additional 7 days of culture in extract-free status (black bars).

\subsection{HPLC Profiles and Algae Inhibitory Effect of Tannic Acid}

The HPLC chromatograms of standard tannic acid and three aqueous extracts, such as walnut husk, rose, and kudzu leaf, are shown in Figure 3. The standard tannic acid showed a cluster band with several small peaks in the 8-12 min retention time. The plant extracts also showed similar patterns of chromatograms to tannic acid. Among the extracts, walnut husk showed the widest ranges of tannin peak area, while rose leaf and kudzu leaf extracts presented $74.5 \%$ and $41.0 \%$ of the walnut husk peak areas, respectively. The differences in quantitative tannic acids among the plant extracts were fairly well matched with the cyanobacterial inhibitory activities of the extracts. It has been reported that tannic acid is usually seen as a broad band in HPLC analysis, because tannic acid is composed of different gallic acid esters of glucose [40]. Therefore, oligomers of hydrolysable tannins have been observed in a broad area of plant-tissue extracts [31,41]. 
A

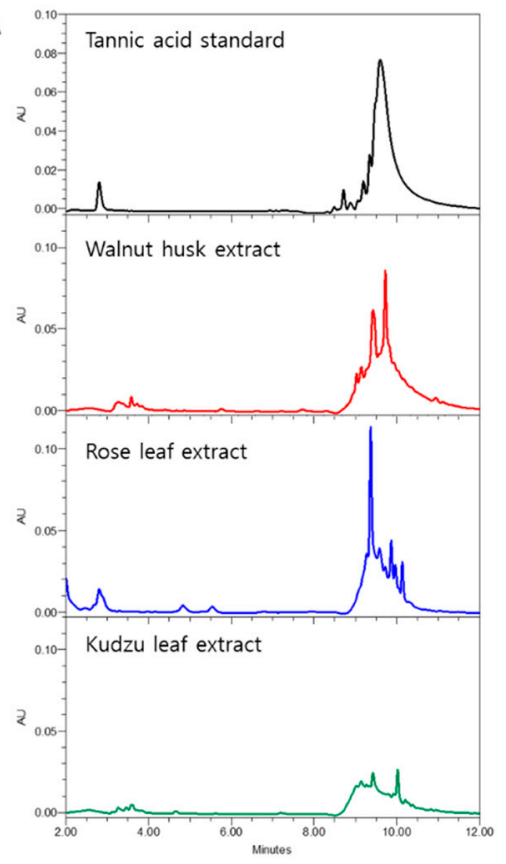

B

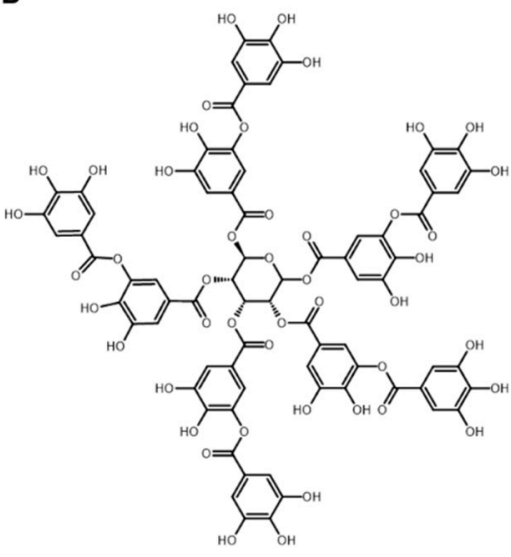

Tannic acid (gallotannin)

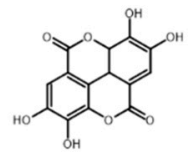

Ellagic acid

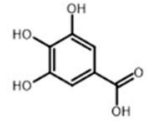

Gallic acid

Figure 3. HPLC chromatograms of standard tannic acid and extracts of walnut husk, rose leaf, and kudzu leaf detected at $280 \mathrm{~nm}$ (A). Structures of major hydrolysable tannins in walnut husk and rose leaf extracts (B).

The inhibitory effects of tannic acid on cyanobacterial reproduction and chlorophyll-a content are shown as $\mathrm{EC}_{50}$ values in Figure 4 . The $\mathrm{EC}_{50}$ values were 20.8 and $17.1 \mu \mathrm{g} \mathrm{mL}^{-1}$ for cell reproduction and chlorophyll-a content, respectively. Švanys et al. [38] reported that both chlorophyll-a content and photosynthetic yields were significantly reduced by tannic acid treatment, with an $\mathrm{EC}_{50}$ value of approximately $24 \mu \mathrm{g} \mathrm{mL}{ }^{-1}$. In addition, it was reported that tannic acid significantly inhibited the chlorophyll-a synthesis of cyanobacterium Nostoc sp. by more than $90 \%$ and reduced the growth rate by lowering the photosystem II and chlorophyll-a content of $M$. aeruginosa $[39,42]$. Walnut husks and rose leaves are rich in polyphenolic compounds, which are allelochemicals with antimicrobial capacity [43-46]. According to these studies, allelopathic effects are caused by high content of hydrolysable tannins and their derivatives, such as ellagic, gallic, and tannic acids $[37,47,48]$. Therefore, it seems reasonable that the degree of tannic acid quantity in our study is a critical factor for cyanobacterial growth inhibition.
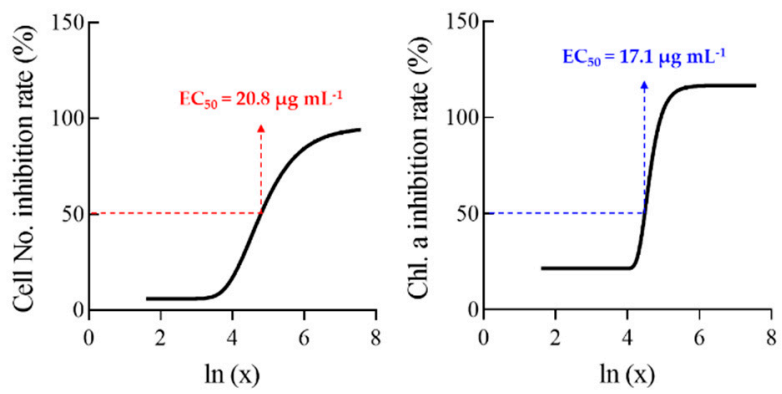

Figure 4. Determination of $\mathrm{EC}_{50}$ values of tannic acid to inhibit cell number and chlorophyll-a content of Microcystis aeruginosa using dose-response curves.

\subsection{Application of Allelopathic Extracts in Hydroponic Culture}

Figure 5 shows the increase in the whole biomass of perilla cultured with or without algae. All perilla seedlings grew rapidly for 5 days regardless of algae and extract treatment. In the untreated extract group (Figure 5A), the increase in biomass did not change from 5 
to 15 days of culture using algae-free medium. However, biomass was continually reduced via culturing using algae-added medium. When the rose leaf or walnut husk extract was added to the medium, the $\mathrm{IC}_{90}$ treatment of each extract contributed to the normal growth of perilla seedlings. In contrast, the $\mathrm{IC}_{50}$ treatment of each extract had no positive effect on perilla growth (Figure 5B,C).
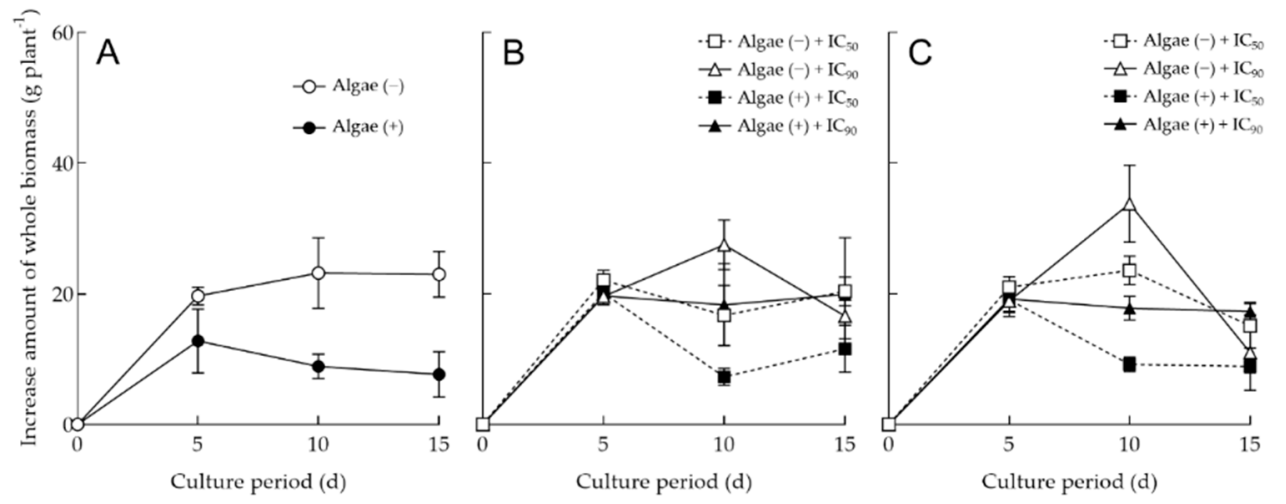

Figure 5. The growth of perilla cultured in algae-free and -treated hydroponic media with (A) nontreatment, (B) rose leaf, and (C) walnut husk extracts for 15 days.

During the initial culture, no negative effect of algae on perilla growth was observed. However, perilla growth after 10 days of culture was negatively affected by the logarithmic expansion of algal density, as shown in Figure 1. No negative effect was observed after $\mathrm{IC}_{90}$ treatment of the allelopathic extracts. Although it has been argued whether algae are either positively or negatively affected by crop growth [49-51], numerous efforts have been made to reduce algal infestation in practical agricultural fields. Because most algae rapidly reproduce and form algal blooms in hydroponic solution [52], excessively reproduced algae compete for nutrients with crops and release allelopathic toxins in certain algal species [6,52].

Perilla leaves were also damaged by the presence of algae (Table 3). In the hydroponic medium, the number of algal cells increased more than five times higher than the initial cell number and presented $579 \times 105$ cells $\mathrm{mL}^{-1}$ after 15 days of culture. When the perilla was cultured in this medium, the leaves were damaged by excessive algal reproduction. The damaged leaves presented the lowest biomass of $0.38 \mathrm{~g} \mathrm{leaf}^{-1}$, and their size was shrunken (Table 3 and Figure 6). When the rose leaf or walnut husk extract was added to the medium, the algal cells slowly or hardly grew for 15 days. Therefore, the leaf biomass increased and leaf size did not shrink, except for the $\mathrm{IC}_{50}$ treatment of rose leaf extract (Table 3 and Figure 6). The chlorophyll content of perilla leaves may be damaged by algal inoculation. The chlorophyll content of algal-damaged leaves was reduced by approximately $15 \%$ compared to that of normal leaves (Table 3). Treatment with allelopathic extracts inhibited algal growth and maintained greenish perilla leaves. However, the $\mathrm{IC}_{90}$ treatment of walnut husk extract only caused a modest reduction in chlorophyll content in the perilla leaves (Table 3 and Figure 6). In the $\mathrm{IC}_{90}$ treatment of walnut husk extract, EC and pH changes did not influence chlorophyll degradation in perilla leaves. There were no significant changes in EC and $\mathrm{pH}$ values during the culture period (Figure S1). The mean values of EC exhibited $2.262 \pm 0.01$ and $2.195 \pm 0.03 \mathrm{mS} \mathrm{cm}^{-1}$ on initial and harvest day, respectively. The EC values were included within a reasonable EC range for perilla growth [28]. In addition, the mean values of $\mathrm{pH}$ were $6.8 \pm 0.02$ and $7.1 \pm 0.06$ on initial and harvest day, respectively. In hydroponics, most vegetables have tolerance within the $\mathrm{pH}$ range of 5.5 to 7.5 , but the targeted $\mathrm{pH}$ is 5.6-5.8 in order to have effective and balanced nutrients absorbance by the plants roots [1]. The walnut husk extract contained a high content of tannins (Figure 3). As an allelochemical, it has been argued whether the effect of tannins on plants is negative. Kraus et al. [53] stated that there is little evidence of the direct effects of tannins on physiological processes in plants. However, other researchers have reported negative 
effects of tannins on some plants. Hydrolysable tannins, especially gallic acid, had an inhibitory effect on the root architecture of Arabidopsis thaliana seedlings in soil [54]. Tannic acid inhibited root elongation in wheat seedlings [55]. In addition, the aqueous extract of Aloe ferox roots, which contain high tannin content, significantly inhibited the germination and initial growth of tomato seeds [56]. Based on these studies, it was confirmed that tannins negatively affect germination and initial growth of seedlings. However, there are few studies on the effect of tannins on mature plants; therefore, it cannot be mentioned that tannins in walnut husk extract directly resulted in the chlorophyll damage in mature perilla leaves. Despite this limitation, our results suggest further studies of tannin effects as an allelochemical.

Table 3. Leaf growth and chlorophyll content of perilla grown under algae-free and -treated hydroponic media with non-treatment, rose leaf, and walnut husk extract.

\begin{tabular}{|c|c|c|c|c|c|}
\hline Extract & $\begin{array}{l}\text { Concentration } \\
\qquad\left(\mathrm{g} \mathrm{L}^{-1}\right)\end{array}$ & $\begin{array}{c}\text { Algae } \\
\text { Inoculation }\end{array}$ & $\begin{array}{c}\text { Algae Harvest } \\
\left(\times 10^{5} \text { cells }^{1} L^{-1}\right)\end{array}$ & $\begin{array}{l}\text { Leaf Biomass } \\
\text { (g DW leaf }^{-1} \text { ) }\end{array}$ & $\begin{array}{c}\text { Chlorophyll } \\
\text { Content } \\
\left(\mathrm{mg} \mathrm{g}^{-1} \mathrm{DW}\right)\end{array}$ \\
\hline \multirow[t]{2}{*}{ Non-treatment } & 0 & - & 0 & $0.52 \pm 0.00 \mathrm{abc}^{2}$ & $10.09 \pm 0.28 \mathrm{abc}$ \\
\hline & 0 & + & $579 \pm 1.93 \mathrm{a}$ & $0.38 \pm 0.06 \mathrm{~d}$ & $8.67 \pm 0.54 \mathrm{de}$ \\
\hline \multirow[t]{4}{*}{ Rose leaf } & $0.6\left(\mathrm{IC}_{50}\right)$ & - & 0 & $0.56 \pm 0.01 \mathrm{a}$ & $10.72 \pm 0.41 \mathrm{a}$ \\
\hline & $0.6\left(\mathrm{IC}_{50}\right)$ & + & $263 \pm 1.59 b$ & $0.42 \pm 0.01 \mathrm{~cd}$ & $10.13 \pm 0.16 \mathrm{ab}$ \\
\hline & $3.5\left(\mathrm{IC}_{90}\right)$ & - & 0 & $0.54 \pm 0.03 \mathrm{ab}$ & $10.72 \pm 0.34 \mathrm{a}$ \\
\hline & $3.5\left(\mathrm{IC}_{90}\right)$ & + & $103 \pm 2.19 \mathrm{~d}$ & $0.49 \pm 0.04 a b c$ & $9.34 \pm 0.20 \mathrm{bcd}$ \\
\hline \multirow[t]{4}{*}{ Walnut husk } & $1.4\left(\mathrm{IC}_{50}\right)$ & - & 0 & $0.46 \pm 0.03 \mathrm{abcd}$ & $9.31 \pm 0.21 \mathrm{bcd}$ \\
\hline & $1.4\left(\mathrm{IC}_{50}\right)$ & + & $172 \pm 1.37 c$ & $0.51 \pm 0.01 \mathrm{abc}$ & $8.81 \pm 0.74$ cde \\
\hline & $4.6\left(\mathrm{IC}_{90}\right)$ & - & 0 & $0.45 \pm 0.04 \mathrm{bcd}$ & $7.94 \pm 0.15 \mathrm{e}$ \\
\hline & $4.6\left(\mathrm{IC}_{90}\right)$ & + & $105 \pm 1.39 \mathrm{~d}$ & $0.45 \pm 0.03 \mathrm{bcd}$ & $6.52 \pm 0.21 \mathrm{f}$ \\
\hline
\end{tabular}

${ }^{1}$ The number of algal cells which were harvested on 15th day after hydroponic culture. ${ }^{2}$ Different letters within a column indicate significant differences at $p<0.05$, according to Tukey's HSD test.

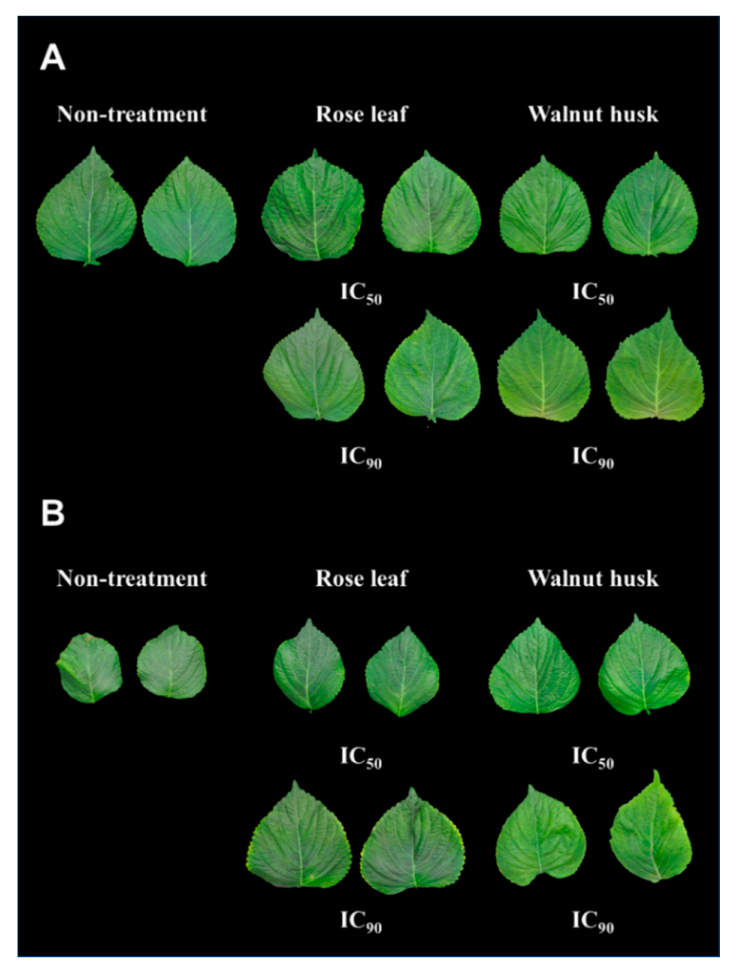

Figure 6. Morphological differences of perilla leaves after 15 days of hydroponic culture using (A) algae-free and (B) treated media with non-treatment, rose leaf, and walnut husk extracts. 


\section{Conclusions}

Our research findings provide the basis for developing methods of utilizing allelopathic extracts to control the growth of harmful algae and using water-soluble allelochemicals derived from plants. Findings from this research can be used to distinguish between ambiguous allelopathic effects on either the inhibition or mortality of algae by measuring the effect of each extract over a long period of time. Two effective extracts to control cyanobacteria were selected: rose leaf and walnut husk extracts. It was confirmed that the extracts contained high amounts of tannins, which mainly contributed as allelochemicals to cyanobacteria. In addition, rose leaf extract was found to be a potentially better resource for cyanobacterial control in agricultural hydroponic culture than walnut husk extract due to different degrees of crop damage caused in the cultivation system.

Supplementary Materials: The followings are available online at https:/ / www.mdpi.com/article / 10.3390 /agronomy11112350/s1, Figure S1. Changes of electrical conductivity and pH of nutrient solutions during hydroponic culture.

Author Contributions: Conceptualization, S.H.E.; methodology, C.S.G. and S.H.E.; software, C.S.G.; validation, S.H.E. and C.S.G.; formal analysis, C.S.G.; investigation, C.S.G., S.D. and J.H.K.; data curation, C.S.G.; writing - original draft preparation, C.S.G.; writing-review and editing, S.H.E. All authors have read and agreed to the published version of the manuscript.

Funding: This research was funded by the National Research Foundation of Korea (NRF), grant number NRF-2019R1A2C1009623.

Institutional Review Board Statement: Not applicable.

Informed Consent Statement: Not applicable.

Data Availability Statement: Not applicable.

Conflicts of Interest: The authors declare no conflict of interest.

\section{References}

1. Huo, S.; Liu, J.; Addy, M.; Chen, P.; Necas, D.; Cheng, P.; Li, K.; Chai, H.; Liu, Y.; Ruan, R. The influence of microalgae on vegetable production and nutrient removal in greenhouse hydroponics. J. Clean. Prod. 2019, 243, 118563. [CrossRef]

2. Wada, T. Theory and Technology to Control the Nutrient Solution of Hydroponics. In Plant Factory using Artificial Light; Elsevier: Amsterdam, The Netherlands, 2019; pp. 5-14. [CrossRef]

3. Hua, Q.; Liu, Y.-G.; Yan, Z.-L.; Zeng, G.-M.; Liu, S.-B.; Wang, W.-J.; Tan, X.; Deng, J.-Q.; Tang, X.; Wang, Q.-P. Allelopathic effect of the rice straw aqueous extract on the growth of Microcystis aeruginosa. Ecotoxicol. Environ. Saf. 2018, 148, 953-959. [CrossRef]

4. Abdel-Raouf, N.; Al-Homaidan, A.A.; Ibraheem, I.B.M. Microalgae and wastewater treatment. Saudi J. Biol. Sci. 2012, 19, 257-275. [CrossRef] [PubMed]

5. Zhang, J.; Wang, X.; Zhou, Q. Co-cultivation of Chlorella spp and tomato in a hydroponic system. Biomass Bioenergy 2016, 97, 132-138. [CrossRef]

6. Yang, J.; Deng, X.; Xian, Q.; Qian, X.; Li, A. Allelopathic effect of Microcystis aeruginosa on Microcystis wesenbergii: Microcystin-LR as a potential allelochemical. Hydrobiologia 2013, 727, 65-73. [CrossRef]

7. Iredale, R.S.; McDonald, A.T.; Adams, D.G. A series of experiments aimed at clarifying the mode of action of barley straw in cyanobacterial growth control. Water Res. 2012, 46, 6095-6103. [CrossRef]

8. Wang, J.; Peng, Y.; Wang, Z.; Zou, W.; Peng, X.; Song, Q. Transcriptional response of Microcystis aeruginosa to the recruitment promoting-benthic bacteria. J. Oceanol. Limnol. 2021, 1-10. [CrossRef]

9. Li, J.; Hu, J.; Cao, L.; Yuan, Y. Growth, physiological responses and microcystin-production/-release dynamics of Microcystis aeruginosa exposed to various luteolin doses. Ecotoxicol. Environ. Saf. 2020, 196, 110540. [CrossRef]

10. Jančula, D.; Maršálek, B. Critical review of actually available chemical compounds for prevention and management of cyanobacterial blooms. Chemosphere 2011, 85, 1415-1422. [CrossRef]

11. Eom, S.H.; Yang, H.S.; Weston, L.A. An Evaluation of the Allelopathic Potential of Selected Perennial Groundcovers: Foliar Volatiles of Catmint (Nepeta $\times$ faassenii) Inhibit Seedling Growth. J. Chem. Ecol. 2006, 32, 1835-1848. [CrossRef]

12. Maksimovi, T.; Hasanagi, D.; Sciences, N.; Luka, B.; Stojanovi, M.; Luka, B. Allelopathic influence of Juglans Regia L. aqueous extract on the germination and the growth of lettuce and tomato. J. Agri. Food Environ. Sci. 2020, 74, 5-12.

13. Chung, I.-M.; Park, S.-K.; Ali, M.; Prabakaran, M.; Oh, Y.-T.; Kim, S.-H.; Siddiqui, N.A.; Ahmad, A. Flavonoid glycosides from leaves and straw of Oryza sativa and their effects of cytotoxicity on a macrophage cell line and allelopathic on weed germination. Saudi Pharm. J. 2018, 26, 375-387. [CrossRef] 
14. Kobayashi, K.; Sasamoto, H.; Sasamoto, Y.; Sugiyama, A.; Fujii, Y. Evaluation of Isoflavones as Allelochemicals with Strong Allelopathic Activities of Kudzu Using Protoplast Co-Culture Method with Digital Image Analysis. Am. J. Plant Sci. 2021, 12, 376-393. [CrossRef]

15. Weston, L.A.; Alsaadawi, I.S.; Baerson, S.R. Sorghum Allelopathy-From Ecosystem to Molecule. J. Chem. Ecol. 2013, 39 , 142-153. [CrossRef]

16. Arora, K.; Batish, D.R.; Kohli, R.K.; Singh, H.P. Allelopathic impact of essential oil of Tagetes minuta on common agricultural and wasteland weeds. Innovare J. Agric. Sci. 2017, 5, 1-4.

17. Neilen, A.D.; Hawker, D.W.; O’Brien, K.R.; Burford, M.A. Phytotoxic effects of terrestrial dissolved organic matter on a freshwater cyanobacteria and green algae species is affected by plant source and DOM chemical composition. Chemosphere 2017, 184, 969-980. [CrossRef]

18. Yuan, R.; Li, Y.; Li, J.; Ji, S.; Wang, S.; Kong, F. The allelopathic effects of aqueous extracts from Spartina alterniflora on controlling the Microcystis aeruginosa blooms. Sci. Total Environ. 2019, 712, 136332. [CrossRef]

19. Wu, L.; Guo, X.; Harivandi, M. Allelopathic effects of phenolic acids detected in buffalograss (Buchloe dactyloides) clippings on growth of annual bluegrass (Poa annua) and buffalograss seedlings. Environ. Exp. Bot. 1998, 39, 159-167. [CrossRef]

20. López, M.L.; Bonzani, N.E.; Zygadlo, J.A. Allelopathic potential of Tagetes minuta terpenes by a chemical, anatomical and phytotoxic approach. Biochem. Syst. Ecol. 2008, 36, 882-890. [CrossRef]

21. de Arruda, G.L.; de Moraes, G.K.A.; Junior, A.F.C.; Araujo, A.R.; Chapla, V.M. Aromatic compounds from the endophytic fungus Asordaria conoidea and their allelochemical property using OSMAC strategy. Nat. Prod. Res. 2021, 1-4. [CrossRef]

22. Yu, S.; Li, C.; Xu, C.; Effiong, K.; Xiao, X. Understanding the inhibitory mechanism of antialgal allelochemical flavonoids from genetic variations: Photosynthesis, toxin synthesis and nutrient utility. Ecotoxicol. Environ. Saf. 2019, 177, 18-24. [CrossRef]

23. Ogunsusi, M.; Akinlalu, A.O.; Komolafe, I.J.; Oyedapo, O.O. Allelopathic effects of alkaloid fraction of Crotalaria retusa Linn on growth and some biochemical parameters of bean seedlings (Phaseolus vulgaris). Int. J. Plant Physiol. Biochem. 2018, 10, 1-9. [CrossRef]

24. Patiño, R.; Rashel, R.H.; Rubio, A.; Longing, S. Growth-suppressing and algicidal properties of an extract from Arundo donax, an invasive riparian plant, against Prymnesium parvum, an invasive harmful alga. Harmful Algae 2018, 71, 1-9. [CrossRef]

25. Tebaa, L.; Douma, M.; Tazart, Z.; Manaut, N.; Mouhri, K.H.; Loudiki, M. Assessment of the potentially algicidal effects of Thymus satureioides Coss. and Artemisia herba-alba L. against Microcystis Aeruginosa. Appl. Ecol. Environ. Res. 2018, 16, 903-912. [CrossRef]

26. Rodolfi, L.; Chini Zittelli, G.; Bassi, N.; Padovani, G.; Biondi, N.; Bonini, G.; Tredici, M.R. Microalgae for oil: Strain selection, induction of lipid synthesis and outdoor mass cultivation in a low-cost photobioreactor. Biotechnol. Bioeng. 2009, 102, 100-112. [CrossRef]

27. Hoagland, D.R.; Arnon, D.I. The water-culture method for growing plants without soil. Circ. Calif. Agric. Exp. Stn. 1950, $347,32$.

28. Nguyen, T.; Yeom, M.-S.; Oh, M.-M. Effect of a Newly-Developed Nutrient Solution and Electrical Conductivity on Growth and Bioactive Compounds in Perilla frutescens var. crispa. Agronomy 2021, 11, 932. [CrossRef]

29. Zhao, W.; Zheng, Z.; Zhang, J.; Roger, S.-F.; Luo, X. Allelopathically inhibitory effects of eucalyptus extracts on the growth of Microcystis aeruginosa. Chemosphere 2019, 225, 424-433. [CrossRef]

30. Lim, Y.J.; Eom, S.H. Effects of different light types on root formation of Ocimum basilicum L. cuttings. Sci. Hortic. 2013, 164, 552-555. [CrossRef]

31. Gu, H.-F.; Li, C.-M.; Xu, Y.-J.; Hu, W.-F.; Chen, M.-H.; Wan, Q.-H. Structural features and antioxidant activity of tannin from persimmon pulp. Food Res. Int. 2008, 41, 208-217. [CrossRef]

32. Kwak, H.; Hegeman, A.; Park, S. Seasonal changes in metabolic profiles of galls and leaves of Rhus chinensis using gas chromatography mass spectrometry and liquid chromatography quadrupole time-of-flight mass spectrometry. J. Plant Biol. 2014, 57, 127-135. [CrossRef]

33. Shen, X.; Su, Y.-C.; Liu, C.; Oscar, T.; DePaola, A. Efficacy of Vibrio parahaemolyticus depuration in oysters (Crassostrea gigas). Food Microbiol. 2018, 79, 35-40. [CrossRef] [PubMed]

34. Canton, M.C.; Holguin, F.O.; Boeing, W.J. Alkaloid gramine to control algal invaders: Algae inhibition and gramine persistence. Bioresour. Technol. Rep. 2019, 7, 100304. [CrossRef]

35. Jose, S.; Gillespie, A.R. Allelopathy in black walnut (Juglans nigra L.) alley cropping. I. Spatio-temporal variation in soil juglone in a black walnut-corn (Zea mays L.) alley cropping system in the midwestern USA. Plant Soil 1998, 203, 191-197. [CrossRef]

36. Terzi, I. Allelopathic effects of juglone and decomposed walnut leaf juice on muskmelon and cucumber seed germination and seedling growth. Afr. J. Biotechnol. 2008, 7, 1870-1874.

37. Jahanban-Esfahlan, A.; Ostadrahimi, A.; Tabibiazar, M.; Amarowicz, R.; Esfahlan, J. A Comprehensive Review on the Chemical Constituents and Functional Uses of Walnut (Juglans spp.) Husk. Int. J. Mol. Sci. 2019, 20, 3920. [CrossRef]

38. Švanys, A.; Eigemann, F.; Grossart, H.-P.; Hilt, S. Microcystins do not necessarily lower the sensitivity of Microcystis aeruginosato tannic acid. FEMS Microbiol. Lett. 2015, 363, fnv227. [CrossRef]

39. Zhao, G.; Watson, J.; Crowder, C.; Stevens, J.S.E. Changes in biological production of the cyanobacterium, Nostoc sp. strain MAC, under subinhibitory concentrations of tannic acid and related compounds. J. Appl. Phycol. 1998, 10, 1-7. [CrossRef]

40. Romani, A.; Campo, M.; Pinelli, P. HPLC/DAD/ESI-MS analyses and anti-radical activity of hydrolyzable tannins from different vegetal species. Food Chem. 2012, 130, 214-221. [CrossRef] 
41. Soong, Y.; Barlow, P. Quantification of gallic acid and ellagic acid from longan (Dimocarpus longan Lour.) seed and mango (Mangifera indica L.) kernel and their effects on antioxidant activity. Food Chem. 2006, 97, 524-530. [CrossRef]

42. Laue, P.; Bährs, H.; Chakrabarti, S.; Steinberg, C.E. Natural xenobiotics to prevent cyanobacterial and algal growth in freshwater: Contrasting efficacy of tannic acid, gallic acid, and gramine. Chemosphere 2014, 104, 212-220. [CrossRef]

43. Oliveira, I.; Sousa, A.; Ferreira, I.; Bento, A.A.; Estevinho, M.L.M.F.; Pereira, J.A. Total phenols, antioxidant potential and antimicrobial activity of walnut (Juglans regia L.) green husks. Food Chem. Toxicol. 2008, 46, 2326-2331. [CrossRef]

44. Carvalho, M.; Ferreira, P.J.; Mendes, V.S.; Silva, R.; Pereira, J.A.; Jeronimo, C.; Silva, B.M. Human cancer cell antiproliferative and antioxidant activities of Juglans regia L. Food Chem. Toxicol. 2010, 48, 441-447. [CrossRef]

45. Maleita, C.; Esteves, I.; Chim, R.; Fonseca, L.; Braga, M.E.M.; Abrantes, I.; de Sousa, H.C. Naphthoquinones from Walnut Husk Residues Show Strong Nematicidal Activities against the Root-knot Nematode Meloidogyne hispanica. ACS Sustain. Chem. Eng. 2017, 5, 3390-3398. [CrossRef]

46. Cunja, V.; Mikulic-Petkovsek, M.; Stampar, F.; Schmitzer, V. Compound Identification of Selected Rose Species and Cultivars: An Insight to Petal and Leaf Phenolic Profiles. J. Am. Soc. Hortic. Sci. 2014, 139, 157-166. [CrossRef]

47. Riffault, L.; Destandau, E.; Pasquier, L.; André, P.; Elfakir, C. Phytochemical analysis of Rosa hybrida cv. 'Jardin de Granville' by HPTLC, HPLC-DAD and HPLC-ESI-HRMS: Polyphenolic fingerprints of six plant organs. Phytochemistry 2014, 99, 127-134. [CrossRef]

48. Jakopic, J.; Colaric, M.; Veberic, R.; Hudina, M.; Solar, A.; Stampar, F. How much do cultivar and preparation time influence on phenolics content in walnut liqueur? Food Chem. 2007, 104, 100-105. [CrossRef]

49. Bayona-Morcillo, P.J.; Plaza, B.M.; Gómez-Serrano, C.; Rojas, E.; Jiménez-Becker, S. Effect of the foliar application of cyanobacterial hydrolysate (Arthrospira platensis) on the growth of Petunia x hybrida under salinity conditions. J. Appl. Phycol. 2020, 32, $4003-4011$. [CrossRef]

50. Castro-Castellon, A.T.; Hughes, J.M.R.; Read, D.S.; Azimi, Y.; Chipps, M.J.; Hankins, N.P. The role of rhizofiltration and allelopathy on the removal of cyanobacteria in a continuous flow system. Environ. Sci. Pollut. Res. 2021, 28, 27731-27741. [CrossRef]

51. Supraja, K.V.; Behera, B.; Balasubramanian, P. Performance evaluation of hydroponic system for co-cultivation of microalgae and tomato plant. J. Clean. Prod. 2020, 272, 122823. [CrossRef]

52. Schwarz, D.; Gross, W. Algae affecting lettuce growth in hydroponic systems. J. Hortic. Sci. Biotechnol. 2004, 79, 554-559. [CrossRef]

53. Kraus, T.E.C.; Dahlgren, R.; Zasoski, R.J. Tannins in nutrient dynamics of forest ecosystems-A review. Plant Soil 2003, 256, 41-66. [CrossRef]

54. Rudrappa, T.; Bonsall, J.; Gallagher, J.L.; Seliskar, D.M.; Bais, H.P. Root-secreted Allelochemical in the Noxious Weed Phragmites australis Deploys a Reactive Oxygen Species Response and Microtubule Assembly Disruption to Execute Rhizotoxicity. J. Chem. Ecol. 2007, 33, 1898-1918. [CrossRef]

55. Kinraide, T.B.; Hagermann, A.E. Interactive intoxicating and ameliorating effects of tannic acid, aluminum $\left(\mathrm{Al}^{3+}\right)$, copper $\left(\mathrm{Cu}^{2+}\right)$, and selenate $\left(\mathrm{SeO}_{4}{ }^{2-}\right)$ in wheat roots: A descriptive and mathematical assessment. Physiol. Plant. 2010, 139, 68-79. [CrossRef]

56. Arowosegbe, S.; Wintola, O.A.; Afolayan, A.J. Phytochemical constituents and allelopathic effect of Aloe ferox Mill. root extract on tomato. J. Med. Plants Res. 2012, 6, 2094-2099. [CrossRef] 